\title{
光渦によるナノ 粒子流の動的制御とその応用 \\ Dynamical control of nanoparticle flow by optical vortex and its applications
}

\author{
○正 川野 聡恭 \\ Satoyuki KAWANO \\ 大阪大学 Osaka University
}

Key Words : Nanofluidics, Optical Vortex, Molecular fluid dynamics, Single molecular measurements, Nanoparticles

Nanofluidics 技術，すなわち，MEMS 加工技術と荷電微粒子の動的流動制御法に，ナノ電極より得られる時空間 電流信号の AI 解析を融合して，花粉アレルゲンやウィルス検出・識別，さらには，電気的 DNA シークエンシン グの高速化を目指している ${ }^{1-13}$.ここでは，ナノスケールのダブルスリットを作製し，直径 $O(100) \mathrm{nm}$ の各種ナノ 粒子に対し，光渦による光圧操作を行うことで，ナノスリットを周期的に通過する公転運動を実現し，そのイオ ン電流信号検出に成功した. また，光渦による粒子公転運動の高速化手段として，粒子同士の流体力学的相互作 用を検討した. Oseen テンソルを用いた数理モデルによるシミュレーションは実験結果と良好な一致を示した.

\section{文献}

(1) C. Hosokawa, T. Tsuji, T. Kishimoto, T. Okubo, S. Kudoh, and S. Kawano, Convection dynamics forced by optical trapping with a focused laser beam, J. Phys. Chem. C 124 (2020), 8323-8333.

(2) K. Doi, N. Asano, and S. Kawano, Development of glass micro-electrodes for local electric field, electrical conductivity, and pH measurements, Sci. Rep. 10 (2020), 4110 1-12.

(3) T. Tsuji, R. Nakatsuka, K. Nakajima, K. Doi, and S. Kawano, Effect of hydrodynamic inter-particle interaction on the orbital motion of dielectric nanoparticles driven by an optical vortex, Nanoscale 12(2020), 6673-6690.

(4) R. Nakamura, H. Kawaguchi, M. Iwata, A. Kaneko, R. Nagura, S. Kawano, K. Toyoda, K. Miyamoto, and T. Omatsu, Optical vortex-induced forward mass transfer: manifestation of helical trajectory of optical vortex, Opt. Express 27 (2019), 38019-38027.

(5) T. Tsuji, Y. Matsumoto, and S. Kawano, Flow with nanoparticle clustering controlled by optical forces in quartz glass nanoslits, Microfluid. Nanofluid. 23 (2019), 126 1-11.

(6) K. Setoura, T. Tsuji, S. Ito, S. Kawano, and H. Miyasaka, Opto-thermophoretic separation and trapping of plasmonic nanoparticles, Nanoscale 11 (2019), 21093-21102.

(7) T. Tsuji, Y. Imada, H. Yamazaki, and S. Kawano, Simultaneous measurement of the oscillation characteristics and electrical voltage output of an artificial cochlear sensory epithelium immersed in a liquid: theory and experiment, Sens. Actuators A Phys. 295 (2019), 414-427.

(8) T. Tsuji, Y. Matsumoto, R. Kugimiya, K. Doi, and S. Kawano, Separation of nano- and microparticle flows using thermophoresis in branched microfluidic channels, Micromachines 10 (2019), 321 1-16.

(9) T. Tsuji, K. Doi, and S. Kawano, Modeling of single-particle translocation through a low-aspect-ratio nanopore, J. Biomech. Sci. Eng. 14 (2019), 18-00539 1-10.

(10) R. Nagura, T. Tsujimura, T. Tsuji, K. Doi, and S. Kawano, Coarse-grained particle dynamics along helical orbit by an optical vortex irradiated in photocurable resins, OSA Continuum 2 (2019), 400-415.

(11) T. Tsuji, Y. Sasai, and S. Kawano, Thermophoretic manipulation of micro- and nanoparticle flow through a sudden contraction in a microchannel with near-infrared laser irradiation, Phys. Rev. Appl. 10 (2018), 044005 1-18.

(12) F. Nito, T. Shiozaki, R. Nagura, T. Tsuji, K. Doi, C. Hosokawa, and S. Kawano, Quantitative evaluation of optical forces by single particle tracking in slit-like microfluidic channels, J. Phys. Chem. C 122 (2018), 17963-17975.

(13) K. Doi, F. Nito, A. Yano, R. Nagura, and S. Kawano, Generation and control of electrohydrodynamic flows in aqueous electrolyte solutions, J. Vis. Exp. 139 (2018) e57820 1-10. 